\title{
Validation Method of Flame-AAS with Microwave Digestion for Mineral Analysis in Carbohydrate-Rich Samples
}

\author{
Imas Solihat $^{1 *}$, Didah Nur Faridah ${ }^{1}$, Nancy Dewi Yuliana ${ }^{1}$ \\ ${ }^{1}$ Department of Food Technology Science, Faculty of Agricultural Technology, \\ Bogor Agricultural University, Bogor, Indonesia \\ *email: imaskhairani@gmail.com
}

Received July 25, 2018; Accepted November 1, 2018; Available online December 8, 2018

\begin{abstract}
One of the effective methods for mineral destruction is by using microwave digestion. However, some parameters in the microwave manual book are different with AOAC method such as the volume of acid, temperature, and the length of destruction time $(\Delta \mathrm{t})$. Thus, a validation for mineral analysis method of Fe, $\mathrm{Zn}$, and $\mathrm{Cu}$ by using microwave digestion method is required. In this study, carbohydrate-rich samples such as rice and canned pineapple were being used for the validation of mineral analysis method of $\mathrm{Fe}, \mathrm{Zn}$, and $\mathrm{Cu}$ using microwave digestion. The parameters of this research include LOD, LOQ, LDM, linearity, precision, accuracy, and reproducibility. The accuracy result for $\mathrm{Fe}, \mathrm{Zn}$, and $\mathrm{Cu}$ mineral was found in the range of 75$120 \%$ with good precision value ( $\%$ RSD $<\%$ 2/3RSD Horwitz). Based on the results, accuracy for mineral $\mathrm{Fe}, \mathrm{Zn}$ and $\mathrm{Cu}$ found in the range of $75-120 \%$ with good precision value (\% RSD <\% 2/3RSD Horwitz). The regression curves of the $\mathrm{Fe}, \mathrm{Zn}$, and $\mathrm{Cu}$ minerals gave the value of $\mathrm{R}^{2}>0.990$. For $\mathrm{LDM}$ values in the rice samples consecutively for $\mathrm{Fe}, \mathrm{Zn}$, and $\mathrm{Cu}$ minerals were 0,$06 ; 0,07 ; 0,04 \mathrm{mg} / \mathrm{L}$, while for the canned pineapple were 0,$07 ; 0,10 ; 0,01 \mathrm{mg} / \mathrm{L}$, respectively. The results of a modified method for minerals $\mathrm{Fe}, \mathrm{Zn}$ and $\mathrm{Cu}$ analysis in carbohydrate-rich samples was not significantly different from AOAC (2012). Thus the method was acceptable to be used in laboratory analysis.
\end{abstract}

Keywords: F-AAS, microwave digestion, an essential mineral, method validation

\section{INTRODUCTION}

The quality of foods product can be seen from the existence of essential minerals such as Fe, $\mathrm{Zn}$, and $\mathrm{Cu}$, etc. There are several analytical methods that can be used for the measurement of those mineral content includes Flame-AAS (Atomic Absorption Spectrophoto-metry with Flame). F-AAS is a quantitative method for mineral analysis based on the atomic absorption when the sample solution is aspirated and transforms into an aerosol (a small form of granules that has a larger surface area). The flame formed an evaporation process and produce crystal salts, and atoms in the ground state absorb electromagnetic waves from the light sources (cathode lamps) and move into excited state, the reduction amount of light intensity that reaches the detector is considered as a measure for the sample concentration (Khalid, Alaama, \& Abbas, 2016). One of a critical phase in this analysis is the reshuffled of an organic form on to solved inorganic and ready to be analyzed by the FAAS.

There are two methods of sample destruction for food mineral analysis; those are dry digestion and wet digestion methods. Dry digestion method is a reshuffle from of organic minerals in the sample into inorganic minerals by sampling paths in a muffle furnace and requires a certain heating temperature. Generally in this dry destruction requires a heating temperature between $400-800 \quad{ }^{\circ} \mathrm{C}$ (Bragg \& Xue, 2011). The flaw in this method is time-consuming it takes 15 minutes to 8 hours (Taylor, Sneddon, Hardaway, Bobbadi, \& Avanthi, 2006). It also might cause some loss of mineral components due to evaporation or adsorption in the furnace wall. Wet digestion is the reshuffling of the sample using acid or acid mixture and heating (Korn, Morte, Santos, \& Castro, 2008). It is not so environmental friendly besides some minerals might be lost due to evaporation. Microwave digestion method is the process of destruction in a sealed vessel using a mixture of the oxidizing solution at $300{ }^{\circ} \mathrm{C}$ and 199 bar (No, 2012). It is an enclosed system which is fast, easy and gives accurate analysis result (Belay $\&$ Tadesse, 2014).

Microwave method which is used for mineral analysis usually comes with its manual which contains the digestion working instruction. Mineral digestion described in the 
manual book is not always the same with those of AOAC standard method AOAC 999.10 (2012). The differences might comprise the volume of reagents used $\left(\mathrm{HNO}_{3}\right.$ and $\left.\mathrm{H}_{2} \mathrm{O}_{2}\right)$, temperature, and the duration of the digestion. Different food matrix might also cause different results of the digestion process, which will result in different mineral analysis results. For the above-mentioned reasons, we conducted validation of microwave digestion method for mineral analysis of carbohydraterich samples such as rice and pineapple. In addition to containing carbohydrate components, rice and pineapple can also serve as a source of essential minerals. This study aims to (1) validate the mineral analysis of $\mathrm{Fe}$, $\mathrm{Zn}$ and $\mathrm{Cu}$ using F-AAS with microwave digestion; (2) obtaining mineral content data of $\mathrm{Fe}, \mathrm{Zn}$, and $\mathrm{Cu}$ on rice and canned pineapple samples using the validated method.

\section{EXPERIMENTAL SECTION}

The research was conducted in five stages: food sampling; instrument performance test; analysis of mineral content by standard AOAC method and modification method (described in the manual book microwave digestion); while for validation parameters of $\mathrm{Fe}, \mathrm{Zn}$ and $\mathrm{Cu}$ mineral analysis including linearity, precision, reproducibility, precision-accuracy, LOD (Limit of detection) and LOQ (Limit of quantitation). The validated method was then used to analyze the content of $\mathrm{Fe}, \mathrm{Zn}$ and, $\mathrm{Cu}$ in rice and canned pineapple.

\section{Materials and Instrumentation}

The materials in this study used standard pure analysis, Aqudest, Nitric Acid $\left(\mathrm{HNO}_{3}\right)$ (Merck KgaA), Hydrogen Peroxide $\left(\mathrm{H}_{2} \mathrm{O}_{2}\right)$ 30\% (Merck KgaA), standard solution Zn 1000 ppm, standard solution Fe 1000 ppm, standard solution of $\mathrm{Cu} 1000$ ppm (CertiPUR Merck KgaA).

Close Microwave Digestion type MDS 6G SINEO, Flame-AAS type Shimadzu AA 2000 and hollow cathode lamp $\mathrm{Fe}, \mathrm{Zn}, \mathrm{Cu}$. Glass tools are washed with soap and brushed, then cleaned. Microwave vessels were also regularly cleaned by $50 \%$ nitric acid solution for $10 \mathrm{~min}$ at $175{ }^{\circ} \mathrm{C}$ (Adams, Chaudri, Rousseau, \& Mcgrath, 2010).

\section{Samples}

Samples of rice and canned pineapple obtained from local supermarkets in Bogor.
The canned pineapple has the same brand, expiration date, and production batch. Fat content in the sample should be low $(<40 \%)$ (Cheng \& Capar, 2014). The rice sample was washed with demineralized water and put in the oven at $80{ }^{\circ} \mathrm{C}$ for 6 hours, then mashed by mortar up to 60 mesh size (Kariyawasam, Godakumbura, Prashantha, \& Premakumara, 2016). The rice was stored in the airtight package at room temperature while the blender canned pineapple sample stored in the freezer. Sampling for rice was done by quartering method and canned pineapple was by homogenization method.

\section{Procedure}

\section{Sample Characteristics}

\section{Homogeneity Test}

Homogeneity tests were carried out by taking samples from a different package, homogenized then divided and incorporated into several polyethylene containers. A randomly packed $(\mathrm{n}=10)$ sample then drawn from each other (subsample), homogenized and then two parts were taken for the analysis of ash content in duplicate (Fiamegos et al., 2016). The value of sampling variance and variance of repeatability analysis calculated as MSB (mean square between or differences between samples) and MSW (mean square within or differences $=$ in the sample) (Sunanti, Samin, \& Supriyanto, 2013).

\section{Analysis of Ash and Water Content (AOAC, 2012)}

Determination of ash content in the sample was done by AOAC 900.02A method while for water content test using AOAC 934.06 and 925.45-gravimetry vacuum oven method.

\section{Mineral Analysis}

\section{Standard Method (Microwave Digestion AOAC 999.10-2012)}

Samples weighed 0.5 grams (dry weight). The weighed sample placed in a vessel and then added five $\mathrm{mL}$ of $\mathrm{HNO}_{3} 65 \%$ and $2 \mathrm{~mL}$ of $\mathrm{H}_{2} \mathrm{O}_{2} 30 \%$. Microwave program settings consist of 4 stages: $300 \mathrm{~W} / 3 \mathrm{~min} / 30^{\circ} \mathrm{C}$; $600 \mathrm{~W} / 5 \mathrm{~min} / 150{ }^{\circ} \mathrm{C} ; 500 \mathrm{~W} / 22 \mathrm{~min} / 180{ }^{\circ} \mathrm{C}$; $300 \mathrm{~W} / 15 \mathrm{~min} / 200{ }^{\circ} \mathrm{C}$. After the digestion process completed, the solution is cooled and diluted with demineralized water at a $25 \mathrm{~mL}$ flask. The above working steps are also carried 
out for blanks (nitric acid and hydrogen peroxide).

\section{Modification Method}

The sample weighed as much as 0.5 grams (dry weight) then seven $\mathrm{mL}$ of $\mathrm{HNO}_{3}$ (p) was added and allowed to stand for $20 \mathrm{~min}$, added two $\mathrm{mL} \mathrm{HNO}_{3}$ (p) and last one $\mathrm{mL} \mathrm{H}_{2} \mathrm{O}_{2}$ $30 \%$. The process of digestion with microwave finish with three stages: $300 \mathrm{~W} / 10 \mathrm{~min} / 30{ }^{\circ} \mathrm{C}$; $600 \mathrm{~W} / 5 \mathrm{~min} / 150{ }^{\circ} \mathrm{C} ; 500 \mathrm{~W} / 15 \mathrm{~min} / 180{ }^{\circ} \mathrm{C}$ for rice and $300 \mathrm{~W} / 10 \mathrm{~min} / 130{ }^{\circ} \mathrm{C} ; 600 \mathrm{~W} / 5$ $\min / 150{ }^{\circ} \mathrm{C} ; 500 \mathrm{~W} / 15 \mathrm{~min} / 190{ }^{\circ} \mathrm{C}$ for canned pineapple. After the digestion process was complete, the solution was allowed to reach room temperature then transferred into a 25 $\mathrm{mL}$ flask and homogenized with demineralized water. The preparation of the blank solution (nitric acid and hydrogen peroxide) is carried out by the same procedure as the sample.

\section{Validation of Analysis Methods}

\section{Precision Test}

This test is measuring the concentration of samples as much as seven times replication for the measurement of 3 types of minerals $(\mathrm{Fe}, \mathrm{Cu}$ and, $\mathrm{Zn}$ ). The value determined by calculating\% RSD analysis. Precision is good if the RSD value analysis is $<2 / 3 \mathrm{CV}$ Horwitz.

\section{Reproducibility}

Reproducibility determined by measuring the concentration of samples in the same laboratory, the same operator at different times. Furthermore, the RSD value of the analysis compared with the RSD Horwitz value. Reproducibility is accepted if it has an RSD value worth smaller than the RSD Horwitz value. Test results at two different weeks tested by using t-test.

\section{Accusations}

This section done by using a sample that spiked with a standard solution. The experimental concentration of spiking is the percentage of the sample concentration $(80 \%$ is low), $100 \%$ is medium, and $120 \%$ is high) which is between the linearity ranges. Added standard performed seven repetitions. Spiking was done at the beginning of the preparation before the microwave digestion. Accuracy determined by calculating percent recovery. Good accuracy is within the range of $75-120 \%$.

\section{Linearity}

Instrument linearity performed by measuring the absorbance of standard solutions of minerals ( $\mathrm{Fe}, \mathrm{Zn}$ and, $\mathrm{Cu}$ ) at various concentrations. The linearity test of $\mathrm{Fe}$ and $\mathrm{Cu}$ minerals used $0-0,5 \mathrm{mg} / \mathrm{L}$ while $\mathrm{Zn}$ mineral concentration was $0-1,0 \mathrm{mg} / \mathrm{L}$. The absorbance of each standard solution was measured and performed repetition three times.

\section{Limit Detection (LOD) and Quantitation Limit (LOQ)}

The values of LDI (Limit detection of instrument) and LOQ can obtained from linearity analysis data by determining the standard of calibration error. Theoretical LDI obtained from the formula $[3(\mathrm{sy} / \mathrm{x})] / \mathrm{b}$. As confirmation was made by seven replicates measurement of the solution according to LDI concentration for each minerals, the LDI value was accepted if the analysis result did not give precision value and accuracy.

The theoretical LOQ derived from [10 $(\mathrm{sy} / \mathrm{x})] / \mathrm{b}$. Confirmation of LOQ values done by making a solution that has a concentration of theoretical LOQ value and measured with seven replicates for each mineral. LOQ is accepted if the data provides an acceptable precision and accuracy value. The LDM (Limit detection of the method) value determined by measuring seven replications of the mineral concentration in the sample prepared according to the theoretical LDI values. The LDM value is accepted if the analysis results do not provide acceptable precision and accuracy value (Riyanto, 2014).

\section{RESULTS AND DISCUSSION}

Before to the measurement, the feasibility of F-AAS test equipment must be done to produce valid data such as determination of flow rate that should not be too big or too small because it will affect the magnitude of flame and atomization process. The sensitivity of the tool is done by using copper $2 \mathrm{ppm}$ solution. The results obtained are $0.0352 \mathrm{ppm}$ below the maximum response requirement of $0.04 \mathrm{ppm}$ (Supriyanto, 2007) so the F-AAS can be using for analysis. Copper 2 ppm solution is used for sensitivity test because it has the ionization potential which is not too small or too big, so it is not easily ionized in flame and is stable, besides Copper, the lead solution also proper for the test.

\section{Test of Sample Characteristics}

The Water content in rice obtained at $9.14 \%$. This is an acceptance with the 
standards of SNI 6128-2015 (BSN, 2015) with a maximum water content of $14 \%$. The water content in canned pineapple obtained $83.41 \%$ according to the requirements of USDA 09269 (USDA, 2016) with a maximum water content of $85.73 \%$.

\section{Sample Homogeneity Test}

The sample homogeneity test was conducted to ensure that the mineral content in each part of the sample was the same and did not contain an interrupt matrix. The values of $\mathrm{F}$ test for rice and canned pineapple each is 1.13 and 0.72 . From the analysis results $F$ test is $<F$ table $\alpha=5 \%$ of 3.02 . From both, the results can be stated that the sample has been homogeneous.

\section{Mineral Analysis}

Digestion is process destruction of organic forms into inorganic forms (Taufiq, Sabarudin, \& Mulyasuryani, 2016). Elements such as $\mathrm{C}, \mathrm{H}, \mathrm{O}, \mathrm{N}, \mathrm{S}$ and, $\mathrm{P}$ will turn into water-soluble oxides such as $\mathrm{CO}_{2}, \mathrm{H}_{2} \mathrm{O}, \mathrm{NO}_{2}$. Close digestion with microwave has several advantages such as requires fewer time, less reactive reagents, more accurate analysis results (Altundag \& Tuzen, 2011) reduces contamination in the sample and reduces the loss of volatile elements (Korn et al., 2008). The digestion process finished marked by the production of a clear solution, which indicates that the organic compound reform is going well. The sample solution is ready to be analyzed using F-AAS. The F-AAS is recommended for use in measuring minerals because of good sensitivity with a detection limit of about $1 \mathrm{ppm}$ and low operational costs (Khalid et al., 2016) (Demirel, Tuzen, Saracoglu, \& Soylak, 2008).

Microwaves are radiation of non-ionic electromagnetic waves, exposed molecules by radiation of microwave rotation of moment dipole without any changes in molecular structure (Belay \& Tadesse, 2014). Microwaves have frequencies of $300 \mathrm{GHz}-300$ $\mathrm{MHz}$ with a wavelength of $1 \mathrm{~mm}-1$ meter. The efficiency of the destruction process by using microwave digestion effected by the volume of acids $\left(\mathrm{HNO}_{3}\right.$ and $\left.\mathrm{H}_{2} \mathrm{O}_{2}\right)$, time and temperature (Momen, Zachariadis, Anthemidis, \& Stratis, 2007).

The process in the destruction with microwave digestion occurs with the mixed sample with acid that inserted within the closed vessel, and then the resulted microwave radiation causes an increase of temperature and pressure. Temperature rise between $30-190{ }^{\circ} \mathrm{C}$ and rising of pressure between (1,1-2,2 $\mathrm{Mpa}$ in a low $\mathrm{pH}$ increase the speed of sample decomposition and solubility in the form of organic matter and convert the sample from the solid to the solution (Yuyun, Peuru, \& Ibrahin, 2017). The high pressure on the vessel will increase the boiling point of the nitric acid thus increasing the oxidation power and accelerating the reaction. The oxidizing agents using $\mathrm{HNO}_{3}$ and $\mathrm{H}_{2} \mathrm{O}_{2}$ oxidize minerals into their salt form. The use of mixed acid is better than that of a single acid for mineral destruction processes (Idera, Omotola, Adedayo, \& Paul, 2015). Nitric acid is being used by the digestion process will be an incomplete result in a cloudy solution (Yang, Yan, Cao, \& Zhang, 2012). The gradient heating system aims to improve the reaction between $\mathrm{NO}$ and $\mathrm{O}_{2}$ to $\mathrm{NO}_{2}$ (Tiago et al., 2015). The resulting $\mathrm{NO}_{2}$ is reabsorbed in acid solution and regenerates $\mathrm{HNO}_{3}$. The addition of $\mathrm{H}_{2} \mathrm{O}_{2}$ will increase the presence of $\mathrm{O}_{2}$ in the vessel (No, 2012).

Carbohydrates in rice formed as a complex starch polymer (amylose and amylopectin). It will swell when contact with water so that the destruction process starts from $30{ }^{\circ} \mathrm{C}$ to $180{ }^{\circ} \mathrm{C}$ gradually. The canned pineapple contains no starch polymer but has a simple sugar content composed of glucose, fructose and, sucrose which has a simpler structure compared to polysaccharides making it easier to crush. Therefore, the digestion process starts at $130{ }^{\circ} \mathrm{C}$ to $190{ }^{\circ} \mathrm{C}$ gradually.

Table 1. The precision test result of mineral analysis

\begin{tabular}{ccccccc}
\hline \multirow{2}{*}{ Sample } & \multicolumn{5}{c}{ Mineral Concentration (mg/kg) } \\
\cline { 2 - 7 } & \multicolumn{5}{c}{ Rice } & \multicolumn{4}{c}{ Canned Pineapple } \\
\cline { 2 - 7 } & $\mathrm{Cu}$ & $\mathrm{Zn}$ & $\mathrm{Fe}$ & $\mathrm{Cu}$ & $\mathrm{Zn}$ & $\mathrm{Fe}$ \\
\hline RSD (\%) & 4.18 & 2.17 & 6.44 & 6.44 & 5.64 & 3.54 \\
2/3CV Horwitz & 9.97 & 6.99 & 7.22 & 7.22 & 11.33 & 6.62 \\
\hline
\end{tabular}


Table 2. Measurement result for LOD and LOQ

\begin{tabular}{ccccc}
\hline \multirow{2}{*}{ Mineral } & LDI $(\mathrm{mg} / \mathrm{L})$ & LOQ $(\mathrm{mg} / \mathrm{L})$ & \multicolumn{2}{c}{$\mathrm{LDM}(\mathrm{mg} / \mathrm{L})$} \\
\cline { 4 - 5 } & & & Rice & $\begin{array}{c}\text { Canned } \\
\text { Pineapple }\end{array}$ \\
\hline $\mathrm{Cu}$ & 0.01 & 0.1 & 0.04 & 0.01 \\
$\mathrm{Zn}$ & 0.02 & 0.2 & 0.07 & 0.10 \\
$\mathrm{Fe}$ & 0.05 & 0.1 & 0.06 & 0.07 \\
\hline
\end{tabular}

According to (Roha, 2012) the content of glucose and fructose in pineapple fruit is $0.51 \%$ and $0.83 \%$. Before the destruction process, both the sample of rice and the canned pineapple are done "pre-destruction" stage (given time lag 20 minutes before the digestion) so that the sample reacts with the oxidizing acid. At high temperatures, mineral ions will activate oxygen atoms from starch which will remove hydrogen from carbon atoms in the glucose unit (Costa et al., 2011). The longer the microwave heating will increase the temperature inside the vessel, lowering the condensation process and eventually increasing the concentration of minerals in solution (Bakkali, Ramos, Souhail, $\&$ Ballesteros, 2009)(Bakkali et al., 2009).

The presence of minerals can affect the quality of foodstuffs such as copper and iron play a role in oxidation-reduction reactions because their oxidative potentials can cause undesirable changes in processed foods associated with browning reactions and fat oxidation resulting in a decreased nutritional value (Damodaran, Parkin, \& Fennema, 2007). Besides iron plays a role in the color changes that occur in meat $\left(\mathrm{Fe}^{2+}\right.$ red, $\mathrm{Fe}^{3+}$ brown). Also, zinc can stabilize the color on canned green beans.

Mineral content of $\mathrm{Fe}, \mathrm{Zn}$ and, $\mathrm{Cu}$ with the standard method and modification obtained p-value $>\alpha=5 \%$ so stated both methods produce data that is not significantly different.
The results of the analysis according to, the mineral content of $\mathrm{Fe}, \mathrm{Zn}$ and $\mathrm{Cu}$ in pineapples respectively are $0,5-30 \mathrm{mg} / \mathrm{kg} ; 0,05-22 \mathrm{mg} / \mathrm{kg}$; 0,04-10 mg/kg.

\section{Validation of Analysis Methods}

\section{Precision}

Precision test results can be seen in Table 1. From the table, it can be seen that the precision for $\mathrm{Fe}, \mathrm{Zn}$ and $\mathrm{Cu}$ for rice and pineapple samples each yield a value of $\%$ RSD <2/3 CV Horwitz.

\section{$L O D$ and $L O Q$}

The detection limit divided into the instrument detection limit (LDI) and the detection limit method (LDM). LDI is the smallest concentration of the analyte that can still be detected by the instrument while the LDM is the smallest concentration of an analyte in the sample still be detected. Detection limits testing using a calibration curve. Quantitative limits are the lowest concentrations of an analyte that can determined with an acceptable level of precision and accuracy (quantity can be determined), the LOQ value is the lower limit of the calibration curve. The measurement results for LDI and LOQ can be seen in Table 2. The LDI values for the three minerals are smaller than those of Silvestre MD et al. (2000) whereas LDI for $\mathrm{Cu}, \mathrm{Fe}$ and $\mathrm{Zn}$ are 0,07 $\mathrm{mg} / \mathrm{mL} ; 0,07 \mathrm{mg} / \mathrm{mL} ; 0,11 \mathrm{mg} / \mathrm{mL}$.

Table 3. The test result for the determination of reproducibility from $1^{\text {st }}$ week and $2^{\text {nd }}$ week and.

\begin{tabular}{|c|c|c|c|c|c|c|}
\hline \multirow{3}{*}{ Repeat } & \multicolumn{6}{|c|}{ Content $(\mathrm{mg} / \mathrm{kg})$} \\
\hline & \multicolumn{2}{|c|}{$\mathrm{Cu}$} & \multicolumn{2}{|c|}{$\mathrm{Zn}$} & \multicolumn{2}{|l|}{$\mathrm{Fe}$} \\
\hline & 1 & 2 & 1 & 2 & 1 & 2 \\
\hline \multicolumn{7}{|c|}{ Rice } \\
\hline Average & 0.94 & 0.87 & 24.34 & 24.48 & 24.72 & 25.01 \\
\hline P-value & \multicolumn{2}{|c|}{0.122} & \multicolumn{2}{|c|}{0.712} & \multicolumn{2}{|c|}{0.546} \\
\hline \multicolumn{7}{|c|}{ Canned Pineapple } \\
\hline Average & 0.43 & 0.41 & 0.67 & 0.69 & 23.82 & 24.11 \\
\hline $\mathrm{P}$-value & \multicolumn{2}{|c|}{0.167} & \multicolumn{2}{|c|}{0.299} & \multicolumn{2}{|c|}{0.375} \\
\hline
\end{tabular}

Acceptance requirement: $p$-value $>\alpha 95 \%$ 
Table 4. Accuracy of mineral from rice and canned pineapple

\begin{tabular}{|c|c|c|c|c|c|c|}
\hline \multicolumn{7}{|c|}{ Recovery (\%) } \\
\hline \multirow[t]{2}{*}{ spiking } & \multicolumn{3}{|c|}{ Rice } & \multicolumn{3}{|c|}{ Canned Pineapple } \\
\hline & $80 \%$ & $100 \%$ & $120 \%$ & $80 \%$ & $100 \%$ & $120 \%$ \\
\hline \multicolumn{7}{|l|}{ mineral } \\
\hline $\mathrm{Fe}$ & 92.16 & 89.78 & 82.05 & 92.28 & 85.53 & 84.14 \\
\hline $\mathrm{Cu}$ & 82.87 & 82.06 & 81.97 & 89.18 & 84.95 & 99.91 \\
\hline $\mathrm{Zn}$ & 84.44 & 85.89 & 86.85 & 93.56 & 103.74 & 90.88 \\
\hline
\end{tabular}

Acceptance requirement: $75-120 \%$

\section{Linearity}

The regression equation produced for $\mathrm{Fe}$ $: \mathrm{y}=0.084 \mathrm{x}-0.0002$ with $\mathrm{R}^{2}=0.9970 ; \mathrm{Cu}: \mathrm{y}=$ $0.1335 \mathrm{x}-0.0004$ with $\mathrm{R}^{2}=0.9969 ; \mathrm{Zn}: \mathrm{y}=$ $0.4125 \mathrm{x}+0.0086$ with $\mathrm{R}^{2}=0.9977$. The test shows good linearity, there is an increase of absorbance response to the increase of mineral concentration in standard solution. The linearity curve obtained has a value $\mathrm{R}^{2}$ greater than 0.990. This value corresponds to the acceptability limit.

\section{Reprodusibility}

Test results for reproducibility can seen in Table 3. The test results show the pvalue $>\alpha$ $5 \%$ for all minerals in rice and canned pineapple with no conclusion significantly different. The sample yields a mineral content that is not different if measured at different times.

\section{Accuracy}

Accuracy aims to see the efficiency of methods based on recovery of standard solutions added to the sample (spiking) (Ajai, Ochigbo, Abdullahi, \& Anigboro, 2014). The results of the test for the mineral accuracy of $\mathrm{Fe}, \mathrm{Zn}$ and $\mathrm{Cu}$ are shown in Table 4. Range value from the three minerals are from 80$100 \%$, the results are still within the acceptance limit of AOAC about $75-120 \%$. Indicates that analytical procedures with modification methods for all mineral are acceptable. \% RSD analysis results in less than 2/3 CV Horwitz.

\section{CONCLUSION}

The method of modification in the process of digestion for the analysis of minerals $\mathrm{Fe}, \mathrm{Zn}$ and $\mathrm{Cu}$ in high carbohydrate samples (rice and canned pineapple) was not significantly different from AOAC (2012) and has acceptably qualified for use in laboratory analysis.

\section{ACKNOWLEDGMENTS}

AKA Bogor Polytechnic as a place to do research and assistance cost given.

\section{REFERENCES}

Adams, M. L., Chaudri, A. M., Rousseau, I., \& Mcgrath, P. A. (2014). Practical Evaluation of Microwave and Conventional Wet Digestion Techniques for the Determination of $\mathrm{Cd}, \mathrm{Cu}$ And $\mathrm{Zn}$ in Wheat Grain, International Journal of Environmental Analytical Chemistry, 83 (4), 37-41.

Ajai, A. I., Ochigbo, S. S., Abdullahi, Z., \& Anigboro, P. I. (2014). Determination of Trace Metals and Essential Minerals in Selected Fruit Juices in Minna, Nigeria, 2014. International Journal of Food Science. Volume 2014, ID 462931, 1-5.

Altundag, H., \& Tuzen, M. (2011). Comparison of Dry, Wet and Microwave Digestion Methods for the Multi-Element Determination in Some Dried Fruit samples by ICP-OES. Food and Toxicology, 49(11), 2800-2807.

AOAC. (2012). Official methods of analysis agricultural chemicals (pp. 237-242). The United States of America. Fifteenth edition. Published by the Association of official analytical chemist inc.

Bakkali, K., Ramos, N., Souhail, B., \& Ballesteros, E. (2009). Characterization of Trace Metals in Vegetables by Graphite Furnace Atomic Absorption Spectrometry after Closed Vessel Microwave Digestion. Food Chemistry, 116(2), 590-594.

Belay, K., \& Tadesse, A. (2014). Comparison of Digestion Methods for Determination of $\mathrm{Pb}$ ( II ), $\mathrm{Cr}$ ( VI ) and Cd ( II ) Contents In Some Ethiopia Spices Using 
Atomic Absorption Spectroscopy. International Journal of Academic Scientific Research, 2(3), 42-53.

Bragg, S., \& Xue, Z. (2011). Optimization of Dry Ashing of Whole Blood Samples for Trace Metal Analysis. American Journal of Analytical Chemistry, 2, 979-983.

BSN. (Badan Standardisasi Nasional). (2015). SNI Beras. Jakarta.

Cheng, J., \& Capar, S. G. (2014). Elemental Analysis Manual for Food and Related Products.

http://www.fda.gov/Food/FoodScienceRe search/LaboratoryMethods/ucm2006954. htm

Costa, E., Cardoso, J., Tatsuo, L., Korn, M., Vitoriano, P., Aurélio, M., \& Arruda, Z. (2011). Influence of Microwave Heating on Fluoride, Chloride, Nitrate and Sulfate Concentrations in Water. Talanta, 85(5), 2707-2710.

Damodaran, S., Parkin, K., \& Fennema, O. R. (Eds.). (2007). Fennema's Food Chemistry (4th ed.). CRC Press.

Demirel, S., Tuzen, M., Saracoglu, S., \& Soylak, M. (2008). Evaluation of Various Digestion Procedures for Trace Element Contents of Some Food Materials, Journal of Hazardous Material, 152, 1020-1026.

Fiamegos, Y., Vahcic, M., Emteborg, H., Snell, J., Raber, G., Cordeiro, F., ... De, B. (2016). Trends in Analytical Chemistry Determination of Toxic Trace Elements in Canned Vegetables. The Importance of Sample Preparation. Trends in Analytical Chemistry, 85, 5766.

Idera, F., Omotola, O., Adedayo, A., \& Paul, U. (2015). Comparison of Acid Mixtures Using Conventional Wet Digestion Methods for Determination of Heavy Metals in Fish Tissues. Journal of Scientific Research \& Reports. 8(7), 1-9.

Kariyawasam, T. I., Godakumbura, P. I., Prashantha, M. A. B., \& Premakumara, G. A. S. (2016). Proximate Composition, Calorie Content and Heavy Metals (As, $\mathrm{Cd}, \mathrm{Pb})$ of Selected Sri Lankan Traditional Rice (Oryza Sativa L.)
Varieties. Italian Oral Surgery. 6: 253256.

Khalid, R. S., Alaama, M., \& Abbas, S. A. (2016). Main Analytical Techniques Used for Elemental Analysis in Various Matrices, (February), Tropical Journal of Pharmaceutical Research. 15 (2) :427434.

Korn, M., Morte, E., Santos, D., \& Castro, J. (2008). Sample Preparation for the Determination of Metals in Food Samples using Spectroanalytical Methods. Applied Spectroscopy Reviews. 43(1) (pp. 67-92).

Momen, A., Zachariadis, G., Anthemidis, A., \& Stratis, J. (2007). Use of Fractional Factorial Design for Optimization of Digestion Procedures Followed by MultiElement Determination of Essential and Non-Essential Elements in Nuts using ICP-OES Technique. Talanta, 71, 443451.

No, J. A. (2012). Talanta Microwave-Assisted Digestion of Organic Samples: How Simple Can it Become?, Talanta. 98, 272-276.

Riyanto. (2014). Validasi \& Verifikasi Metode Uji: Sesuai dengan ISO/IEC 17025, Laboratorium Pengujian dan Kalibrasi (1st ed.). Yogyakarta: Deepublish.

Roha, S. (2012). Physico-Chemical Properties of Pineapple Crown Extract Variety N36 and Bromelain Activity in Different Forms, APCBEE Procedia. 4, 130-134.

Santi, S., Samin, \& Supriyanto, C. (2013). Penetapan Nilai Kandidat IN-House Reference Material (RM) ZrO2. Jurnal Sains dan Teknologi Nuklir Indonesia, Vol 14 (1):23-36.

Supriyanto, C. (2007). Unjuk Kerja Metode Flame Atomic Absorption -Spectrometry (F-AAS) Pasca Akreditasi, Pustek Akselerator dan Proses Bahan-BATAN. (2), 246-250.

Taufiq, M., Sabarudin, A., \& Mulyasuryani, A. (2016). Pengembangan dan Validasi Metode Destruksi Gelombang Mikro untuk Penentuan Logam Berat Kadmium dan Timbal dalam Cokelat dengan 
Spektoskopi Serapan Atom (SSA). Journal of Chemistry. 5(2): 31-37.

Taylor, P., Sneddon, J., Hardaway, C., Bobbadi, K. K., \& Avanthi, K. (2014). Sample Preparation of Solid Samples for Metal Determination by Atomic Spectroscopy - An Overview and Selected Recent Applications Sample Preparation of Solid Samples for, Applied Spectroscopy Reviews. (July 2014), 41 (1) 37-41.

Tiago, J., Barbosa, P., Santos, C. M. M., Peralta, V. N., Flores, E. M. M., Korn, M., Korn, A. (2015). MicrowaveAssisted Diluted Acid Digestion for Trace Elements Analysis of Edible Soybean Products, Food Chemistry. 175, 212-217.
[USDA]. United States Department of Agriculture. (2016). Nutrient for Standard Reference Canned Pineapple. USDA Publisher. New York.

Yang, L., Yan, Q., Cao, Y., \& Zhang, H. (2012). Determination of Mineral Element of Some Coarse Grains by Microwave Digestion with Inductively Coupled Plasma Atomic Emission Spectrometry. European-Journal of Chemistry, 9(1), 93-98.

Yuyun, Y., Peuru, A., \& Ibrahin, N. (2017). Analisis Kandungan Logam Berat Timbal dan Kadmium pada Pengolahan Ikan Asin di Kabupaten Banggai Kepulauan. Journal of Pharmacy, 3, 71-76. 